* Mestrando em Direito pela Universidade de Caxias do Sul, USC, Brasil. Especialista em Direito Ambiental em 2005 pela Universidade Luterana do Brasil, ULBRA, Brasil.

Graduado em Direito em 1998 pela Universidade Luterana do Brasil, ULBRA, Brasil. Email: amariotti@via-rs.net.

** Mestranda em Direito pela Universidade de Caxias do Sul, USC, Brasil. Graduada em Direito em 2013 pela Universidade de Caxias do Sul, USC, Brasil. Email: bru. sfernandes@hotmail.com.

*** Doutor em Direito em 2006 pela Universidade do Vale do Rio dos Sinos, UNISINOS, Brasil.

Mestre em Direito em 1999 pela Universidade do Vale do Rio dos Sinos, UNISINOS, Brasil. Especialista em Teoria Geral do Direito em 1996 pela Universidade de Caxias do Sul, UCS, Brasil.

Graduado em Direito em1992 pela Universidade de Caxias do Sul, UCS, Brasil.

Email: calunelli@gmail.com.

\section{Proteção Ambiental, Democracia REPRESENTATIVa e ACESSo À Justiça}

\author{
EnVironmental Protection, \\ RePresentative Democracy and Access \\ TO JUSTICE
}

\begin{abstract}
Alexandre Abel Mariotti* Bruna Souza Fernandes** Carlos Alberto Lunelli****
\end{abstract}

Como citar: MARIOTTI, Alexandre Abel; FERNANDES, Bruna Souza; LUNELLI, Carlos Alberto. Proteção ambiental, democracia representativa e acesso à justiça. Scientia Iuris, Londrina, v. 21, n. 3, p.9-42, nov. 2017. DOI: $10.5433 / 2178-8189.2017 \mathrm{v} 21 n 3 p 9$. ISSN: $2178-$ 8189.

Resumo: Numa sociedade democrática, o cidadão passa aos mandatários eleitos os seus desejos, porém não é possível que a população participe de maneira ativa se não possuir educação ambiental e acesso à informação. $\mathrm{O}$ trabalho aborda a relação entre a democracia representativa, o direito à informação e educação e o reflexo desta relação no âmbito do Poder Judiciário, sendo este o garantidor dos direitos assegurados na Constituição Federal. Assim, é preciso que a justiça possua meios de garantir celeridade em tais questões, porque em matéria ambiental a duração razoável do 
processo é ponto crucial. Para esta pesquisa foi utilizado o método hermenêutico e a técnica de pesquisa bibliográfica.

Palavras-chave: Democracia representativa. Direito ambiental. Acesso à justiça.

Abstract: In democratic societies, citizens transfer their wishes to elected representatives; however, it goes without notice that active participation is not possible if the population lacks environmental education and access to information. In light of this, this paper addresses the relationship between representative democracies; the right to information and education; and the reflection of this in the judiciary branch - who is a protector of the liberties and rights of the Federal Constitution. Moreover, an effective justice needs to be prompt in guaranteeing these issues because for environmental questions, a lawsuit's duration plays a crucial role. This research used the hermeneutic method and the technique of bibliographical research.

Keywords: Representative democracy. Environmental right. Access to justice. 


\section{INTRODUÇÃO}

A atual Constituição da República Federativa do Brasil consolida o Estado Democrático de Direito e a partir deste alicerce constatam-se dois tipos de democracia: a participativa e a representativa. A primeira é constantemente analisada pela doutrina nacional no âmbito do Direito Ambiental por ter reflexo em importantes instrumentos na área, como a iniciativa popular, o plebiscito e o referendo. A segunda - em que o mandatário exerce função em virtude do voto recebido nas eleições permanece em segundo plano. E é nessa, a democracia representativa, que é aprofundado o estudo deste trabalho em virtude de sua relevância. Portanto, o problema a ser enfrentado é se a proteção do bem ambiental pode ser realizada por intermédio de uma democracia representativa desinformada e sem o conhecimento acerca do meio ambiente, assim como dos instrumentos legais que lhe são disponibilizados.

Este artigo aborda, inicialmente, o modo dispensado pelo constituinte para a construção da democracia representativa, apresentando a forma disposta na Constituição sobre a proteção do bem ambiental, bem como a efetiva participação de uma sociedade que se espera consciente no momento de votar.

Num segundo momento, é apresentada a forma e importância dos direitos a informação e a educação ambiental, assim como esses se organizam e capacitam os cidadãos para uma efetiva defesa do meio ambiente.

Por fim, discute-se a necessária participação do Estado na construção do exercício pleno da educação ambiental com um amplo acesso à informação aos cidadãos, tendo o Poder Judiciário como assegurador desses direitos e baluarte de uma possível proteção ambiental 
pela sociedade. Para tanto, o princípio da inafastabilidade da jurisdição, garantido constitucionalmente, assegura a possibilidade de se recorrer ao Poder Judiciário para a garantia de direitos, sendo abordada a questão do acesso à justiça quanto ao exercício da democracia e proteção ambiental.

Deste modo, tem-se que as questões ambientais não podem esperar por soluções, já que se está à beira de um colapso e, por tal motivo, há necessidade de se travar um debate sério e aprofundado sobre a imprescindibilidade de conscientizar a população acerca de uma poderosa ferramenta que lhe é disponibilizada para a mudança: o voto consciente aos mandatários, o qual efetivamente represente os anseios da população na proteção do bem ambiental. Porém, a consciência com relação ao voto e com relação às questões ambientais só nascerá a partir do momento em que o direito à informação e o direito à educação forem amplamente assegurados.

\section{A DEMOCRACIA REPRESENTATIVANA CONSTITUIÇÃO FEDERAL}

A proteção ambiental é tema relevante que precisa ser objeto de discussão, mas de forma abrangente para que todos tomem consciência dos desafios que a humanidade enfrenta para garantir a sobrevivência da espécie humana. Quando se trata de questão ambiental não se almeja apenas à sobrevivência das presentes gerações, mas uma vida digna para as presentes e futuras gerações não se permitindo que as gerações futuras paguem o preço do descaso em que vive a presente geração e em que viveram as gerações passadas.

Ost (1997, p. 395) afirma que "uma coisa é certa: a responsabilidade em relação às gerações futuras e a elaboração de um patrimônio natural 
comum, começam aqui e agora. Eles não têm outro advogado de defesa que não o cidadão, o utilizador e o consumidor que nós somos".

A Constituição Federal de 1988 estabelece que a democracia é o regime político de governo, destacando a necessidade de proteção ambiental em seu artigo 225: "Todos têm direito ao meio ambiente ecologicamente equilibrado, bem de uso comum do povo e essencial à sadia qualidade de vida, impondo-se ao Poder Público e à coletividade o dever de defendê-lo e preservá-lo para as presentes e futuras gerações" (BRASIL, 1988). Nesse sentido, preocupa-se com a questão da participação popular como forma de incluir a sociedade como um todo nas questões que envolvem o meio ambiente.

Ora, o Brasil é possuidor de um dos maiores patrimônios ecológicos da Terra. Defender esse patrimônio constitui tarefa ingente e obrigatória da humanidade, como fator de sua própria sobrevivência. Aliás, como já visto, a Constituição brasileira ressalva que a defesa e preservação do meio ambiente devem ser alcançadas não apenas no interesse das presentes gerações, mas também das futuras. Ao preceito jurídico acrescenta-se a obrigação ética de solidariedade da espécie humana e o planeta Terra (MILARÉ, 2014, p. 223).

Por sua vez, a participação popular encontra-se disposta no artigo $1^{\circ}$, parágrafo único, da Constituição da República Federativa do Brasil: "todo o poder emana do povo, que o exerce por meio de representantes eleitos ou diretamente, nos termos desta Constituição" (BRASIL, 1988), instituindo-se o regime democrático. Com relação ao meio ambiente, o fundamento genérico da participação popular está disposto no caput do citado artigo 225 da Constituição (CANOTILHO, 
2015, p. 201).

Quando se abordada à questão da coletividade em defesa do meio ambiente, é essencial discutir quem é o povo, porque é pelo povo que o Estado manifesta a sua vontade, sendo o povo nada mais do que o conjunto de pessoas que fazem parte de um Estado, ou seja, povo é o substrato humano do território de um determinado Estado - não há Estado sem povo. E nesta senda, é o Direito que determina se alguém faz ou não parte do povo de determinado Estado. O povo é, portanto, a união de cidadãos, "titular de direitos e deveres". E neste interim, é importante a distinção entre povo e população, porque a população é a totalidade de pessoas que estão no Estado, isto é, a população é o grande grupo que a abrange o povo (BASTOS, 1995, p. 18-73).

A democracia constitucional deve ser percebida como sendo um governo do povo, pelo povo e para o povo, no sentido de que o povo é soberano; emana poder e emite decisões - pelas maiorias e por seus representantes -, e deve visar o bem comum dos indivíduos e da comunidade (BIELSCHWSKI, 2013, p. 88).

Canotilho e Leite (2011, p. 184) destacam que a atual Constituição é "extremamente aberta" em sentido democrático ambiental, pois busca a participação de "todos" na defesa e na preservação do meio ambiente. Ou seja, a problemática da política ambiental só poderá ser resolvida quando houver o reconhecimento que o meio ambiente, o Estado e os cidadãos são apenas um e a partir desse reconhecimento, sejam "garantidos instrumentos de ação conjunta".

Dessa forma, o Direito Ambiental “exige ações de cidadania compartilhada entre Estado e cidadãos, utilizando mecanismos precaucionais, preventivos, de responsabilização, de preservação e reconstituição", de forma a assegurar aquilo que já existe (bem ambiental) 
e não apenas se preocupar em criar o que ainda não existe (direitos sociais - habitação, saúde) (LEITE; AYALA, 2004, p. 39).

Nesse sentido, a Constituição Federal é o reflexo do desejo de se ter uma sociedade livre, justa e solidária - como é trazido no texto constitucional, artigo $3^{\circ}$, I (BRASIL, 1988), como um dos objetivos fundamentais - tal objetivo para ser alcançado, necessita de uma democracia (representativa e participativa), "capaz de realizar os valores de igualdade, liberdade e fraternidade" (MATTOS NETO; LAMARÃO NETO; SANTANA, 2012, p. 9). Assim, quando dispõe em seu texto a possibilidade de uma democracia realizada pelos representantes eleitos ou diretamente, contempla a possibilidade de realização conjunta da democracia representativa com a democracia participativa ou direta. Logo, a produção de decisões políticas advindas da atuação de representantes eleitos (vereadores, prefeitos, deputados estaduais, governadores, deputados federais, senadores e presidente da República) ou diretamente dos eleitores, abre a perspectiva de um modelo misto, de democracia semidireta. Neste passo, a Constituição Federal estabelece que “a soberania popular será exercida pelo sufrágio universal e pelo voto direto e secreto, com valor igual para todos, e, nos termos da lei, mediante: I - plebiscito; II - referendo; III - iniciativa popular” (art. 14) (AGRA; BONAVIDES; MIRANDA, 2009, p. 72).

Tratar-se-á apenas uma forma de exercício da soberania popular, a democracia representativa (pela eleição de representantes), como objeto desse estudo, pois quando abordada em conjunto com o Direito Ambiental é matéria menos discutida que a forma participativa e porque é questão de alta relevância no atual momento político do país. Na forma representativa, mesmo que a visualização seja mais difícil, o povo exerce seu poder soberano de escolha e participação, desde as eleições, com 
a escolha de seus representantes, pelo voto direto, secreto e universal, conforme prescreve o artigo 60, $4^{\circ}$, II (BRASIL, 1988). Além disso, o representante eleito deve exercer seu mandato visando atingir aquilo que o povo almeja, nesse sentido destaca Comparato (2012, p. 204): “O representante, mesmo em direito público, age por conta do representado; vale dizer, os poderes que o representante exerce não lhe pertencem, mas lhe foram delegados pelo povo, a quem ele deve prestar contas do exercício do mandato."

Na mesma linha Chaui (1997, p. 289) leciona que "representar é estar no lugar de, falar por e agir por”. Ou seja, a pessoa do representante é portadora da "multiplicidade dos representados". Assim, o representante, com seus atos, deve refletir aquilo que o povo almeja.

Mesmo que a palavra representação tenha diversos significados, talvez o conceito mais simples de representação seja o enunciado por Ribeiro (2001, p. 30) ao afirmar que a representação é "tornar presente o ausente". Dessa forma, se não é possível comparecer a uma assembleia é feita uma procuração para que alguém seja o representante. Assim, o ausente, torna-se presente. Outro conceito de democracia representativa de fácil compreensão é a formulada por Bobbio (1987, p. 44):

A expressão "democracia representativa" significa genericamente que as deliberações coletivas, isto é, as deliberações que dizem respeito à coletividade inteira, são tomadas não diretamente por aqueles que delas fazem parte, mas por pessoas eleitas para esta finalidade. Ponto e basta.

Milaré (2014, p. 215), para demonstrar que o mandatário é, no sentido mais simples da palavra, apenas um representante, afirma que em 
um regime democrático o Poder Público é “poder”, mas é limitado por ser exercido "tão somente no interesse geral da população, particularmente em se tratando de interesses difusos e da tutela de bens indisponíveis".

Como exemplo da importância que um mandatário exerce no Estado brasileiro Comparato (2012, p. 205) destaca as emendas constitucionais, em que o povo delega o poder, a cada legislatura, aos novos representantes eleitos. Porém, o autor destaca que o povo não tem consciência de que, a cada eleição, está outorgando plenos poderes ao Congresso Nacional para emendar a Constituição. Assim, o exercício da soberania popular por meio da eleição de novos representantes, que se dá num espaço curto de tempo, a cada dois anos (eleições municipais e eleições estaduais e federais) concede um poder grandioso ao povo, por vezes desperdiçado, uma vez que não se reflete sobre a importância do voto, o qual transfere aos representantes eleitos o poder de contribuir ou não para questões importantíssimas, entre elas a questão ambiental, como bem esclarece Ost (1997, p. 395): “é o debate democrático, agora interpelado pela urgência de desafios inéditos, que deverão proceder as decisões suscetíveis de infletir na nossa forma de habitar a terra." Nesse mesmo sentido, destaca-se:

Portanto, a democracia constitucional é aquela que representa essa "alma única" existente entre soberania popular e direitos fundamentais, entre liberdades positivas e liberdades negativas, entre igualdade formal e igualdade material, enfim, entre liberdade e igualdade. Mais precisamente, a democracia constitucional registra-se como sendo o regime politico essencialmente comprometido com a dignidade da pessoa humana, encarando esta enquanto marco cultural comum e integralizador da comunidade jurídico-política que caracteriza o 
Estado Democrático de Direito (BIELSCHWSKY, 2013, p. 93-94).

Com relação à consciência na hora do voto, Ribeiro (2001, p. 33) afirma que há pessoas que votam com mais consciência e outras menos, umas refletem sobre os candidatos e programas e outras agem como se a eleição fosse uma loteria. E reconhece ainda que a "boca de urna" é um sinal de que muitas pessoas chegam no dia das eleições indecisas quanto ao voto.

O fato é que a vontade da maioria dos cidadãos deve prevalecer, mas o Estado de Direito nem sempre é garantia de segurança jurídica. $\mathrm{O}$ que o rege, essencialmente, é o regime democrático. É a democracia que sustenta os direitos inerentes do cidadão e essa proteção não acontece em regimes totalitários ou ditatoriais, onde havendo um golpe se suspenderá a garantia dos direitos fundamentais (SIRVINSKAS, 2008, p. 156). Nesse mesmo viés, sustenta Chaui (1997, p. 296) que "não é demais lembrar que, durante sua vigência, o regime autoritário se afirma e se considera um regime repressivo".

Com relação ao poder na democracia é interessante a visão de Rocha (1998, p. 102), quando assegura que a democracia esvazia o poder, porque ele passa da mão de um para a mão de todos e por isso pertence a todos e a ninguém. Não se pretende dizer que o Estado deixe de ser o polo fundamental das decisões, mas a soberania é deslocada do monopólio para o social. O autor sustenta que a democracia gera indeterminação social, porque deixa de existir a legitimidade centralizada para que passe a existir um direito à legitimidade a ser conquistado. Ela gera uma nova forma social, que se baseia na legitimação do conflito e consequentemente na criação das suas próprias regras. Nessa seara sustenta 
Ou seja, a crise do direito implica numa crise de governabilidade e, entre outras consequências, na decretação de irracionalidade da opinião pública, na incapacidade dos especialistas em operacionalizar a razão estratégica e, principalmente, para os nossos interesses nesse texto, na decretação da falência do direito e da democracia (ROCHA, 1998, p. 163).

$\mathrm{Na}$ realidade, o poder popular é instrumento da democracia representativa, sem o qual ela não existiria. Para que o poder popular seja chamado de democrático há necessidade de existir a "livre escolha, em intervalos regulares, dos governantes pelos governados", ou seja, o poder popular precisa ser outorgado e renovado da mesma forma que não existe democracia se uma parcela significativa da população não tiver o direito ao voto. Touraine (1996, p. 42-43) avalia que a impossibilidade das mulheres votarem (que já foi superado) assim como a proibição do voto àqueles que não atingiram determinada idade (ainda em vigor) cria um desequilíbrio no corpo eleitoral, porque gera um maior número de votos da parcela da população aposentada e idosa.

Bobbio (1987, p. 55) tem uma visão divergente, com relação ao desenvolvimento democrático, quando afirma que não importa o número de eleitores, mas sim o número de instâncias não políticas nas quais é possível exercer o direito ao voto, ou seja, o desenvolvimento da democracia se dá com a ocupação dos espaços “dominados por organizações de tipo hierárquico ou burocrático". Nessa linha diz o autor

Hoje, se se quer apontar umíndice do desenvolvimento democrático este não pode mais ser o número de pessoas que têm o direito de votar, mas o número de instâncias (diversas daquelas políticas) nas quais se 
exerce o direito de voto; sintética mas eficazmente: para dar um juízo sobre o estado da democratização num dado país o critério não deve mais ser o de "quem" vota, mas o de "onde" se vota (e fique claro que aqui entendo o "votar" como ato típico e mais comum do participar, mas não pretendo de forma alguma limitar a participação do voto) (BOBBIO, 1987, p. 56).

Para que a democracia, a partir da eleição pelo povo de seus representantes, não se trate apenas de um mero procedimento, é necessário que os direitos fundamentais sejam assegurados e que os indivíduos se sintam cidadãos para terem uma participação efetiva. Assim, é preciso que o Estado e a sociedade civil permaneçam ligados pela representatividade dos mandatários, pois é a partir da interdependência entre direitos fundamentais, cidadania e representatividade que a democracia é constituída (TOURAINE, 1996, p. 43).

Como afirma Müller (2013, p. 74) "se a política não for sumariamente feita considerando o interesse da população real do país, a 'Democracia' representará, sobretudo, apenas um sistema formal'. Nessa mesma linha afirma Ribeiro (2001, p. 32): "Na democracia o voto não é mero procedimento (como o sorteio), e sim a expressão da igualdade e liberdade. Somos livres e, portanto, decidimos nosso destino político. Somos iguais, e por isso nenhum voto vale mais que o outro."

Existe a ideia de que o voto tem valor igual para todos, não importando quaisquer distinções, como é a regra no Direito brasileiro, conforme segue:

Isso significa: ao converter-nos em "cidadãos", cada um de nós é só um centro de "imputação" (que diria 
Kelsen: algo assim como um lugar geométrico de referência) de "direitos de liberdade"; nada importa: a raça, o sexo, a cultura, a riqueza, a pobreza... reais, nem nossas distintas cargas de deveres, que nos fariam ver-nos como somos, ou seja, diferentes: como "cidadãos" somos iguais. E graças a essa igualdade, nosso voto é igual: pesa, influi o mesmo, o do cigano e o do camponês, o do banqueiro e o do aposentado... $\mathrm{E}$, efetivamente, os votos contam iguais (CAPELLA, 1998, p. 140).

Já Ribeiro (2001, p. 33) faz uma reflexão com relação ao valor do voto entre aqueles que fazem uma escolha consciente e aqueles que não a fazem e deixa o seguinte questionamento: "É legítimo igualar os votos de quem escolheu conscientemente e de quem não o fez?”.

Para que o povo como um todo exerça sua cidadania como forma de proteção ambiental, é fundamental que esteja informado e educado. Não é possível uma participação ativa sem o mínimo de conhecimento acerca do assunto e da importância da discussão. Nesse sentido Canotilho (2015, p. 202) afirma "que a participação popular se completa com a informação e a educação ambiental. Destaque-se que a participação sem informação adequada não é credível nem eficaz, mas mero ritual”. Nesse viés, as próximas questões a serem destacadas nesse estudo são os direitos de informação e educação ambiental.

\section{O DIREITO À INFORMAÇÃO E À EDUCAÇÃOAMBIENTAL}

A informação é matéria estabelecida no artigo $5^{\circ}$, XIV e XXXIII da Constituição Federal de 1988: “é assegurado a todos o acesso à informação" e "todos têm direito a receber dos órgãos públicos informações de seu interesse particular, ou de interesse coletivo ou geral" 
(BRASIL, 1988). No que refere à matéria ambiental o texto constitucional trouxe previsão no artigo $225, \S 1^{\circ}$, IV ao “exigir, na forma da lei, para instalação de obra ou atividade potencialmente causadora de significativa degradação do meio ambiente, estudo prévio de impacto ambiental, a que se dará publicidade" (BRASIL, 1988). Ou seja, o texto constitucional tem a consciência que "sem informação adequada não há democracia e não há Estado de Direito" (MACHADO, 2006, p. 49).

Weschenfelder (2012, p. 216) conceitua o direito à informação ambiental como o "direito de transmitir, receber e procurar informações ambientais". Como o direito à informação é forma de receber informações, o texto Constitucional demonstra que ela não pode ficar apenas nas mãos das autoridades e o princípio democrático reforça essa ideia. Por isso, todos devem acesso às informações que dizem respeito ao meio ambiente, até porque todos são responsáveis pela proteção ambiental. (GOMES; SIMIONI, 2014, p. 128). Com relação a esse direito, a CF/88 estabelece apenas algumas restrições, elencadas conforme segue:

Os dispositivos constitucionais evidenciados demonstram que todas as pessoas têm direito à informação, e que a CF estabelece apenas as seguintes restrições: a) a imprescindibilidade do sigilo à segurança da sociedade e do Estado (art. $5^{\circ}$, inc. XXXIII); b) a inviolabilidade da intimidade, da vida privada, da honra e da imagem das pessoas (art. $5^{\circ}$, inc. X); c) na excepcionalidade do estado de sítio decretado em caso de comoção grave de repercussão nacional ou ocorrência de fatos que comprovem a ineficácia de medida tomada durante o estado de defesa (art. 137, inc. I), poderão (poderão, que é faculdade) ser tomadas contra as pessoas, entre outras medidas constitucionais previstas expressamente, restrições relativas à prestação de informações e à 
liberdade de imprensa, radiodifusão e televisão, na forma da lei (art. 139, inc. III) (WESCHENFELDER, 2012, p. 219).

A informação visa à educação da pessoa e da comunidade, além disso, ela possibilita a chance à pessoa informada de se posicionar e se pronunciar sobre a matéria em questão (MACHADO, 2014, p. 123). As informações sobre o meio ambiente devem formar a opinião pública e o mais importante, formar a consciência ambiental. O povo, que é o destinatário da informação precisa opinar sobre as questões de seu interesse (MACHADO, 2014, p. 125).

Nesse sentido, vale destacar o Princípio 10 da Declaração do Rio de Janeiro sobre Meio Ambiente e Desenvolvimento de 1992, que é um modelo a ser seguido:

A melhor maneira de tratar as questões ambientais é assegurar a participação, no nível apropriado, de todos os cidadãos interessados. No nível nacional, cada indivíduo terá acesso adequado às informações relativas ao meio ambiente de que disponham as autoridades públicas, inclusive informações acerca de materiais e atividades perigosas em suas comunidades, bem como a oportunidade de participar dos processos decisórios. Os Estados irão facilitar e estimular a conscientização e a participação popular, colocando as informações à disposição de todos. Será proporcionado o acesso efetivo a mecanismos judiciais e administrativos, inclusive no que se refere à compensação e reparação de danos (ONU, 1992).

Importante destacar a necessidade da informação porque não existe a possibilidade de prevenção de riscos de danos de uma 
determinada atividade se não se sabe sequer que tal atividade vem sendo desenvolvida. Da mesma forma que o desconhecimento do dano ou do risco de dano pode inviabilizar a busca dos meios processuais cabíveis (LEITE; AYALA, 2004, p. 331). Nesse viés, destaca Machado (2006, p. 50) que "a democracia nasce e vive na possibilidade de informar-se. O desinformado é um mutilado cívico". Por isso, o direito à informação a todos e dever de informação pelo Estado é tão importante quando se trata da questão democrática do país.

A democracia, como garantia de escolher os representantes do povo pelo voto é uma arma poderosa no avanço das políticas públicas em matéria ambiental, porém enquanto não existir uma sociedade informada e preparada para exercer a cidadania de forma plena, o meio ambiente continuará a ser degradado. Nessa perspectiva:

Precisamos, por conseguinte, de uma verdadeira democracia, instaurando processos de reflexão e de deliberação o mais amplos possível, em que os cidadãos, na sua totalidade, participem. O que, por seu turno, só será possível se os cidadãos em causa dispuserem de uma verdadeira informação, de uma verdadeira formação e de ocasiões de exercerem na prática o seu juízo (CASTORIADIS, 2007, p. 307).

A democracia não se realiza apenas com a consulta, mas com a efetiva deliberação, conforme segue:

Além disso, à possibilidade de discussão deve se seguir necessariamente a possibilidade de deliberação pelos sujeitos participantes dos temas discutidos; com efeito, a democracia realiza-se não na mera consulta, mas na possibilidade efetiva dos cidadãos decidirem 
questões políticas (BENTO, 2003, p. 248-249).

A opinião pública, formada pelo acesso à informação desempenha papel importante na proteção ambiental. Cidadãos bem informados têm melhores condições de atuarem em sociedade, de articularem seus desejos, ideias e de se tornarem parte nas decisões de seus interesses (MILARÉ, 2014, p. 219). Assim, "só se conseguirão realizar as tarefas essenciais e prioritárias quando o Estado tiver a seu lado nessa missão a coletividade educada, informada e participativa." (LEITE; AYALA, 2004, p. 44).

Quando se discute a opinião pública é importante mencionar a lição de Cervi (2010, p. 61) que destaca as diferenças entre sociedade e massa. A sociedade age por padrão definido e de consenso, já a massa age pela simples convergência de escolhas individuais. Assim, a opinião pública - que não é unânime, é produto da coletividade - só pode ser obtida através da discussão pública. Nesse sentido o mesmo autor destaca: "A formação da opinião pública exige, além da compreensão coletiva, que as pessoas estejam dispostas a partilhar experiências e a fazer concessões (o que não se encontra na massa)."

Com relação às grandes massas Bastos (1995, p. 51) afirma que essas não têm "condições de tomar decisões ponderadas e refletidas", tendo em vista que a psicologia social identificou "fenômenos de despersonalização do indivíduo quando envolvido em movimentos multitudinários." Por essa razão, o autor acredita que a democracia representativa é a única viável atualmente.

Da mesma maneira que o amplo acesso à informação é indispensável para assegurar uma democracia representativa consciente, porque forma a opinião pública da sociedade através do conhecimento 
dos fatos e aspectos importantes que dizem respeito ao direito ambiental, o direito à educação também tem papel importante nesse sentido. No ordenamento jurídico o direito à educação ambiental toma papel de destaque a partir do momento que o texto constitucional assegura tal direito.

A Constituição da República Federativa do Brasil incumbiu ao Poder Público o dever de "promover a educação ambiental em todos os níveis de ensino e a conscientização pública para a preservação do meio ambiente", conforme o art. 225, $\S 1^{\circ}$, VI. Tal disposição constitucional significa um marco importante no Estado brasileiro, que, de maneira atual, reconhece a necessidade da educação ambiental como pressuposto para a conscientização e preservação ambiental (CANOTILHO, 2015, p. 202).

Não cabe ao Estado apenas proteger o meio ambiente, mas criar mecanismos que assegurem de forma efetiva a informação, educação e participação da sociedade nas questões ambientais que dizem respeito a toda uma coletividade. Logo, em sua dimensão social, cabe ao Estado de Direito "entre outras funções, proteger e defender o meio ambiente, promover educação ambiental, criar espaços de proteção ambiental, executar o planejamento ambiental". (CANOTILHO; LEITE, 2011, p. 182).

A educação é ferramenta de formação e exercício da cidadania, por isso, a sociedade como um todo deve agir de maneira cidadã para que uns aprendam com os exemplos dos outros.

A educação ambiental para a formação da cidadania, assim como para o seu exercício, deve estar imbuída 
da cidadania como valor individual e coletivo e, por isso, mãe, pais, professores e agentes públicos da Administração da Educação devem ter formação e praxis de cidadania dentro da concepção de que educação se faz também com exemplos de quem educa (WESCHENFELDER, 2012, p. 191).

Diante disso, o Estado brasileiro vem tomando medidas de incentivo à educação ambiental desde 1999 consoante se constata com a publicação da Lei n ${ }^{\circ}$ 9.795, que instituiu a Política Nacional de Educação Ambiental (PNEA). É desta lei que se extrai o conceito de educação ambiental

Entendem-se por educação ambiental os processos por meio dos quais o indivíduo e a coletividade constroem valores sociais, conhecimentos, habilidades, atitudes e competências voltadas para a conservação do meio ambiente, bem de uso comum do povo, essencial à sadia qualidade de vida e sua sustentabilidade. (art. $1^{\circ}$ ) (BRASIL, 1999).

Destaca-se que o dever de promover e incentivar a educação ambiental não é apenas do Poder Público, mas de diversos atores sociais, conforme disposto no artigo $3^{\circ}$ da PNEA que encarrega além do Poder Público, as instituições educativas, os órgãos integrantes do Sistema Nacional de Meio Ambiente - SISNAMA, os meios de comunicação de massa, as empresas, as entidades de classe, as instituições públicas e privadas e a sociedade como um todo. Dessa forma, qualquer um dos citados, quando deixa de fomentar ações de incentivo à educação ambiental desrespeita a PNEA.

Fica, pois, claro que esse dispositivo reforça a magnitude e 
importância da educação ambiental para o exercício de uma participação democrática efetiva. No mesmo sentido, Pelicioni e Philippi Junior (2014, p. 7) lecionam que educar no caminho da cidadania responsável prepara homens e mulheres para exigirem seus direitos e cumprirem com seus deveres a fim de construir uma cultura de democracia.

Além da necessidade de que todos ajam de forma cidadã, para garantir a verdadeira dimensão da educação ambiental é necessário que as formas de prevenção do dano sejam disponibilizadas de forma ampla e organizada "desde o início do processo intelectivo, bem como no decorrer de todo o desenvolvimento educacional". Além disso, deve haver "incentivo à pesquisa, à publicação dos resultados e a inovações tecnológicas", bem como a "democratização da educação", na criação de uma consciência ambiental, para que todos tenham condições de participar de forma eficiente. O Estado não pode exigir que as pessoas atuem sem que antes seja assegurada a instrução necessária (GOMES; SIMIONI, 2014, p. 130).

A informação ampla é de suma importância quando se trata de assegurar uma sociedade ativa e engajada em melhorar a problemática ambiental. Porém, a educação é o ponto de partida, pois de nada adianta o poder de exercer a democracia se não estiver assegurado o acesso às informações adequadas. Se a educação ambiental não for oferecia com qualidade, as pessoas não conseguirão organizar as informações que recebem e se posicionar de forma crítica.

A informação e consequente participação só se completam com a educação ambiental, de forma a ampliar a consciência e estimulá-la no que diz respeito aos valores ambientais. Em uma rede interligada de informação, participação e educação, 
a última é a base das demais, pois só munido de educação pertinente é que o cidadão exerce seu papel ativo, com plenitude (CANOTILHO, 2015, p. 202).

Em sentido contrário, posiciona-se Weschenfelder (2012, p. 230) quando entende que é a informação ambiental e não a educação ambiental indispensável, porque é a informação que demonstra as relações sociais:

Por mais completa que seja a educação ambiental, é a informação ambiental que vai fornecer os elementos ditados pela dinâmica da vida social. A informação ambiental é igualmente indispensável à concretização do paradigma ambiental e social do direito de propriedade privada e da ordem econômica.

Independentemente de qual posição possui a maior relevância, é sabido que ambas devem ser oferecidas com qualidade, não existindo uma com maior destaque que a outra na medida em que ambas se complementam.

No entanto, frise-se que a educação ambiental encontra certas dificuldades que impedem a sua realização com efetividade, que segundo Weschenfelder (2012, p. 206-230) ainda serão enfrentadas por um longo período. Entre tais dificuldades encontram-se "a filosofia capitalista da maximização do lucro, o mercantilismo, o consumismo e o denominado ‘jeitinho brasileiro’ e corrupção.”

Em qualquer caso, a grande dificuldade para a sua realização é a visão que o ser humano ainda possui de que a natureza é apenas uma forma de produzir lucros e tudo ou quase tudo se reduz ao comércio, no qual, até mesmo os alunos se transformam clientes e os professores vendedores de educação. Por isso, é importante ter em mente que 
escolaridade e educação não são sinônimos, ou seja, ter escolaridade, não significa obrigatoriamente ter educação. $\mathrm{O}$ homem na busca incessante pela felicidade confunde "ser feliz com ter felicidade".

O aspecto desafiador na questão da educação ambiental é educar o indivíduo, tendo consciência de que ele é parte integrante do todo em um complexo de relações, sem esquecer de que se trata de um ser humano inserido em seu meio - social, físico, político. "Dessa forma, a ideia é ter consciência que o homem é parte do todo." (LUNELLI, 2010, p. 18).

Como afirma Castoriadis (2007, p. 315), há a necessidade de um equilíbrio entre a humanidade e os recursos do planeta "para toda política verdadeira e séria”. E, para a construção desse novo modelo político será preciso alterar a forma de posicionamento dos cidadãos (com o voto consciente) e do Estado, no que diz respeito à proteção do ambiente.

Todavia, não se trata de uma tarefa simples, mas é com mudanças na base da educação e no amplo acesso de todos a informação - mesmo àqueles que ainda não tenham consciência da relevância do debate que a mudança positiva pode acontecer. Mesmo que se pense apenas na preservação da espécie humana ou na solidariedade intergeracional, atitudes precisam ser tomadas. "O passado não pode ser transformado, mas o presente e o futuro podem ser construídos de forma a propiciar um autêntico direito à vida digna.” (LUNELLI, 2010, p. 21).

\section{PROTEÇÃO DO AMBIENTE E ACESSO À JUSTIÇA}

A grande dificuldade, quando se trata de proteger o ambiente, é a quase certa irreparabilidade do dano. Portanto, é preciso deixar de esperar que os danos ocorram para depois tomar providências, mesmo porque por mais que se tente reparar o dano ambiental, retornar ao equilíbrio 
anterior, sem vestígios do dano é praticamente impossível.

A índole humana, sendo como é - ou seja, a maioria das pessoas espera até que o problema realmente piore antes de tomar uma ação -, precisa de uma crise ou de um desastre para fazer um planejamento ambiental e iniciar as transições que estivemos discutindo (ODUM; BARRET, 2007, p. 469).

O sistema jurídico brasileiro filtra os riscos ambientais de maneira dúplice -administrativa e judicialmente - formando uma interação dinâmica multidimensional de gerenciamento dos riscos ambientais. Tal filtragem, a partir da união entre política e Direito, através da atuação da administração pública e do Poder Judiciário, demonstra a preocupação com a solidariedade intergeracional.

Nestas condições, tudo aquilo que puder se tornar um risco com relação à qualidade de vida das futuras gerações ou que puder restringir sob qualquer forma o acesso das futuras gerações aos recursos naturais, deve ser objeto de gerenciamento, como forma de evitar qualquer lesão futura. Por isso, o Poder Judiciário, quando provocado, através dos instrumentos competentes (Ação Civil Pública, a Ação Popular Ambiental e o Mandado de Segurança Coletivo, entre outros) faz a avaliação dos riscos, desde que na seara administrativa fique comprovada a manutenção da intolerabilidade dos riscos, devendo ser decidido acerca dos riscos lícitos e ilícitos (STEINMETZ; AUGUSTIN, 2011, p. 119-123).

Por mais que os danos ambientais ultrapassem as fronteiras do país, há pelo menos aos mais atentos a possibilidade de recorrer ao Poder Judiciário procurando evitar que o dano ocorra e, para a maioria da sociedade - ainda desinformada e sem a adequada educação ambiental 
- a procura pela reparação dos danos ambientais, sendo o Judiciário "o guardião das promessas", como conceitua Garapon (2001).

De fato, vivemos em uma sociedade de risco, que está sujeita a catástrofes em escala planetária e que minimamente exerce uma cidadania solidária e participativa, considerando a exigência de proteção de um bem que pertence a todos de forma difusa, e não seu viés individualista e tradicional (LEITE; AYALA, 2004, p. 317).

A nova cidadania ambiental é mais abrangente e não está circunscrita espacialmente a um determinado território ou ligada a um determinado povo oriundo da significação clássica de nação; tem ela como "objetivo comum a proteção intercomunitária do bem difuso ambiental", fugindo dos elementos referidos da cidadania clássica (LEITE; AYALA, 2004, p. 317).

No ordenamento jurídico existe a possibilidade de participação popular a partir da escolha dos representantes políticos, que é de grande valia desde que realizada com consciência, porque é entregue às mãos dos representantes a voz do povo a partir do voto e a democracia participativa (plebiscito, referendo, inciativa popular) e por fim, pelo amplo acesso à Justiça, previsto na Constituição Federal em seu artigo $5^{\circ}, \mathrm{XXXV}$ da Constituição Federal que dispõe que "a lei não excluirá da apreciação do Poder Judiciário lesão ou ameaça a direito.” (BRASIL, 1988).

É correto e justo dizer que, no Direito moderno, o legislador que atribui o benefício (qualidade ambiental) ou a missão (proteger o meio ambiente como dever de todos) também distribui, explícita ou implicitamente, os meios e, entre eles, os 
instrumentos processuais e meios administrativos de participação no esforço de implementação. Logo, é possível extrair da norma reconhecedora da tutela ambiental, como valor essencial da sociedade, um potencial poder processual de participar do processo decisório administrativo ou ingressar em juízo em favor próprio ou de outros cobeneficiários (CANOTILHO; LEITE, 2011, p. 96).

Convém destacar que na existência de uma sociedade e um Estado omissos, onde não são abertos debates para se tratar da problemática ambiental, onde não exista interação e nem participação, os danos ambientais frequentemente ocorrem. Porém, como última alternativa, além da educação, da informação e da participação, há a possibilidade de um ordenamento jurídico que, no caso brasileiro, se preocupa em apontar um último caminho a ser tomado, uma alternativa à sociedade de risco que não se preocupa em prevenir os danos, ou seja, o fortalecimento do acesso ao Poder Judiciário, uma vez que "a sociedade contemporânea é fundamentalmente imprudente" (CASTORIADIS, 2007, p. 308). Logo, quando não restar alternativa para evitar ou reparar o dano é possível o amplo acesso aos meios processuais cabíveis.

Outro mecanismo do Estado democrático do ambiente é o acesso amplo à discussão de controvérsias, na esfera do Poder Judiciário, ou seja, via tutela jurisdicional ambiental. Os meios judiciais são, de fato, o último recurso contra a ameaça e a degradação ambiental, pois antes dessas existem os mecanismos de prevenção e precaução (CANOTILHO; LEITE, 2011, p. 188).

Por mais que o acesso à Justiça deva ser uma alternativa e 
não uma regra, de nada serviriam todas as garantias dadas à sociedade se não houvesse o Poder Judiciário para garantir que tais garantias sejam amplamente asseguradas pelo Estado. "Sem a possibilidade de questionamento coletivo, administrativo e judicial, dos comportamentos degradadores de terceiros, qualquer garantia dada ao cidadão estará gravada com o símbolo da infecundidade e ineficácia do discurso jurídico.” (CANOTILHO; LEITE, 2011, p. 96).

Com relação à democracia representativa e expressão dos três poderes, é válido destacar que não se tem no ordenamento brasileiro eleições para o Poder Judiciário.

Por via das eleições, em tese, pode-se escolher todos os integrantes do Estado. Isso, contudo, não ocorre. As eleições são utilizadas, tão somente, para preenchimento dos cargos de cúpula dos Poderes do Estado, mais especificamente do Legislativo e do Executivo. É muito raro haver eleição para provimento de cargos no Poder Judiciário. Contudo, no Legislativo as eleições desempenham um papel primordial. É este o órgão, por excelência, representativo da vontade popular (BASTOS, 1999, p. 204).

Por certo que questões são levantadas com relação aos limites de atuação do Poder Judiciário quando se trata de assuntos que envolvem os outros dois poderes, uma vez que a neutralidade político-partidária dos magistrados, que auxilia na imparcialidade das decisões, gera uma questão conflitante quando se percebe que juízes que não foram eleitos pelo povo tomam decisões que caberiam aos representantes eleitos, devendo isso ser um limitativo da sua atuação. Nesse sentido Bielschwsky (2013, p. 154) afirma: "Para tanto, uma democracia constitucional 
faz-se fortalecida por uma adequada separação dos poderes, e suas características funcionais de check and balance, para que assim o poder contenha o poder."

Além de levantar a problemática da ausência de escolha dos representantes no Poder Judiciário, o que se pretende a partir desse estudo é perceber que para que haja uma proteção ambiental oriunda da consciência da democracia representativa é necessário que o Estado participe ativamente, desde a garantia de uma educação plena na área - que não seja apenas de forma superficial -, até o amplo acesso à informação. E mais, assegurando o amplo acesso à justiça com qualidade e sem morosidade, porque em matéria ambiental um processo sem respeitar o princípio da razoável duração do processo pode ser a concretização do dano. “A introdução de visão democrática ambiental proporcionará uma vertente de gestão participativa no Estado, que estimulará o exercício da cidadania, com vistas ao gerenciamento da problemática ambiental” (CANOTILHO; LEITE, 2011, p. 183).

Seja como for é importante à percepção de que o bem ambiental “é bem de interesse público, cuja administração e gestão e cujo uso devem ser compartilhados e solidários com toda a coletividade, inspirados em um perfil de democracia ambiental" (CANOTILHO; LEITE, 2011, p. 184-185).

Não se pretende advogar uma "defesa bucólica da natureza" (CASTORIADIS, 2007, p. 306), nem basear o trabalho na deep ecology ou ecologia profunda (OST, 1997, p. 279), tão pouco criar uma “crise de vínculos e de limites", como conceituada por Ost (1997, p. 9). Mas sim apontar o poder que a Constituição colocou nas mãos do povo, ou seja, a possibilidade de participar ativamente na escolha dos mandatários, os quais têm o dever de assegurar os desejos de todos os brasileiros nas 
matérias ambientais, a partir "de uma reconstrução política da sociedade, que a tornasse uma democracia efetiva, e não apenas nas palavras" (CASTORIADIS, 2007, p. 306).

\section{CONSIDERAÇÕES FINAIS}

O Brasil possui grande riqueza quando se trata de meio ambiente, porém a vida na sociedade de risco - que não se preocupa em evitar o dano, mas apenas em repará-lo - tem gerado desastres ambientais. Mesmo que haja a intenção de reparar o dano, quando se fala em meio ambiente é um tanto quanto difícil, ou quase impossível a reparação sem sequelas à natureza.

Nesse sentido, é preciso que seja criada uma consciência ecológica para que a população participe ativamente das decisões que envolvem o meio ambiente. Porém, uma sociedade ativa só será alcançada com o amplo acesso à informação, educação e participação. Não há possibilidade de alguém ser contra ou a favor de determinado assunto se não possuir o conhecimento necessário para defender alguma posição e votar em representantes que efetivamente reflitam os ideais do cidadão. O conhecimento adquirido nesse sentido precisa ter reflexos efetivos.

Porém, é inegável que uma parcela da população continua sem perceber a força que um mandatário possui e quantos benefícios para a área ambiental poderiam ser gerados a partir da escolha de representantes preocupados com essa questão.

O ponto central do trabalho foi demonstrar a importância da democracia representativa na seara ambiental, muito embora o conhecimento sobre uma maior discussão com relação à política participativa (plebiscito, referendo, inciativa popular) e uma visualização 
mais clara da sua aplicação.

Mesmo que não se alcance o desejado - evitar os danos ambientais pela atuação de mandatários imbuídos da salvaguarda ambiental - a Constituição Federal nos permite recorrer ao Poder Judiciário, com o amplo acesso à justiça, que não pode se omitir frente a uma lesão ou ameaça de lesão. Nesse sentido, além da Constituição assegurar a participação popular na seara ambiental, também se preocupa com as ferramentas judiciárias, permitindo que aqueles que desejam tenham a quem recorrer.

Dúvida não há, existem questões controversas no que tange ao Poder Judiciário pelo fato de seus membros não serem eleitos pelo povo, o que gera, de certa forma, limites em sua atuação, o que o leva, por força do princípio da inafastabilidade jurisdicional, a tomar decisões de cunho administrativo e/ou político que desagrada parcela da sociedade imbuída da salvaguarda do meio ambiente.

É sabido que vivemos uma fase crucial com relação ao meio ambiente e é preciso que medidas eficazes sejam adotadas, não importa se por crença na solidariedade intergeracional ou apenas pela simples aplicação da matéria constitucional. O que importa apenas é que uma crise foi criada e agora precisa ser solucionada.

\section{REFERÊNCIAS}

AGRA, Walber Moura; BONAVIDES, Paulo; MIRANDA, Jorge. Comentários à Constituição Federal de 1988. Rio de Janeiro: Forense, 2009.

BASTOS, Celso Ribeiro. Curso de teoria do estado e ciência política. 
3. ed. São Paulo: Saraiva, 1995.

BASTOS, Celso Ribeiro. Curso de teoria do estado e ciência política. 4. ed. São Paulo: Saraiva, 1999.

BENTO, Leonardo Valles. Governança e governabilidade na reforma do estado: entre eficiência e democratização. Barueri: Manole, 2003.

BIELSCHWSKY, Raoni Macedo. Democracia constitucional. São Paulo: Saraiva, 2013.

BOBBIO, Norberto. $O$ futuro da democracia: uma defesa das regras do jogo. 3. ed. Rio de Janeiro: Paz e Terra, 1987.

BRASIL. Constituição (1988). Constituição da República Federativa do Brasil. Disponível em: <http://www.planalto.gov.br/ ccivil_03/constituicao/constituicaocompilado.htm>. Acesso em: 16 jun. 2016.

BRASIL. Lei $\mathbf{n}^{0}$ 9.795, de 27 de abril de 1999. Dispõe sobre a educação ambiental, institui a Política Nacional de Educação Ambiental e dá outras providências. Disponível em: $<$ http://www. planalto.gov.br/ccivil_03/leis/L9795.htm>. Acesso em: 16 jun. 2016.

CANOTILHO, José Gomes. Direito constitucional ambiental brasileiro. 6. ed. São Paulo: Saraiva, 2015. 
CANOTILHO, José Joaquim Gomes; LEITE, José Rubens Morato (Org.). Direito constitucional ambiental brasileiro. São Paulo: Saraiva, 2011.

CAPELLA, Juan Ramón. Os cidadãos servos. Tradução de Lédio Rosa de Andrade e Têmis Correia Soares. Porto Alegre: Sergio Antonio Fabris, 1998.

CASTORIADIS, Cornelius. Uma "democracia" sem a participação dos cidadãos: a força revolucionária da ecologia. In: . Uma sociedade à deriva: entrevistas e debates, 1974-1997. Tradução de Miguel Serras Pereira. Lisboa: 90 Graus, 2007. p. 49-89.

CERVI, Emerson Urizzi. Opinião pública e comportamento político. Curitiba: Ibpex,2010.

CHAUI, Marilena de Souza. Cultura e democracia: o discurso competente e outras falas. 7. ed. São Paulo: Cortez, 1997.

COMPARATO, Fábio Konder. Rumo à justiça. 2. ed. São Paulo: Saraiva, 2012.

GARAPON, Antoine. O juiz e a democracia: o guardião das promessas. 2. ed. Rio de Janeiro: Revan, 2001.

GOMES, Renata Nascimento; SIMIONI, Rafael Lazzarotto. A aplicação do princípio da informação no direito ambiental brasileiro, na forma de 
confiança e risco em Niklas Luhmann. Revista Direito Ambiental e Sociedade, Caxias do Sul, v. 4, n. 2, p. 128, 2014. Disponível em: $<$ http:// www.ucs.br/etc/revistas/index.php/direitoambiental/article/view/3341>. Acesso em: 15 jun. 2016.

LEITE, José Rubens Morato; AYALA, Patryck de Araújo. Direito ambiental na sociedade de risco. 2. ed. Rio de Janeiro: Forense, 2004.

LUNELLI, Carlos Alberto. Direito, ambiente e políticas públicas. Curitiba: Juruá, 2010.

MACHADO, Paulo Affonso Leme. Direito à informação e meio ambiente. São Paulo: Malheiros, 2006.

MACHADO, Paulo Affonso Leme. Direito ambiental brasileiro. 22. ed. São Paulo: Malheiros, 2014.

MATTOS NETO, Antonio; LAMARÃO NETO, Homero; SANTANA, Raimundo Rodrigues. Direitos humanos e democracia inclusiva. São Paulo: Saraiva, 2012.

MILARÉ, Édis. Direito do ambiente. 9. ed. São Paulo: Revista dos Tribunais, 2014.

MÜLLER, Friedrich. Quem é o povo? 7. ed. São Paulo: Revista dos Tribunais, 2013. 
ODUM, Eugene P.; BARRET, Gary W. Fundamentos da ecologia. Tradução de Pégasus Sistemas e Soluções. São Paulo: Thomson Learning, 2007.

ONU. Declaração do Rio sobre meio ambiente e desenvolvimento. Rio de janeiro, 1992. Disponível em: <http://www.google. com.br/url? sa $=$ t \& rct $=j \& q=\&$ esrc $=$ s \& source $=$ we b \& $\mathrm{cd}=$

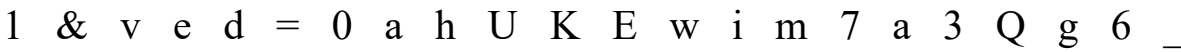
NAhVJE5AKHVHYBmQQFggeMAA\&url=http\%3A\%2F\%2Fwww. onu.org.br\%2Frio2 0\%2Fimg\%2F $2012 \% 2$ F $01 \% 2$ Frio 92. pdf\&usg=AFQjCNHFKf2BN6LorigOQfJ9nZNq4wwt7Q>. Acesso em: 17 jun. 2016.

OST, François. A natureza à margem da lei: a ecologia à prova do direito. Lisboa: Instituto Piaget, 1997.

PELICIONI, Maria Cecília Focesi; PHILIPPI JUNIOR, Arlindo. Bases políticas, conceituais, filosóficas e ideológicas da educação ambiental. In: PHILIPPI JUNIOR, Arlindo;

PELICIONI, Maria Cecília Focesi. (Org.). Educação ambiental e sustentabilidade. 2. ed. Barueri: Manole, 2014. v. 1, p. 3-12.

RIBEIRO, Renato Janine. A democracia. São Paulo: Publifolha, 2001.

ROCHA, Leonel Severo. Epistemologia jurídica e democracia. São Leopoldo: Universidade do Vale do Rio dos Sinos, 1998.

SIRVINSKAS, Luís Paulo. Tutela constitucional do meio ambiente: 
interpretação e aplicação das normas constitucionais ambientais no âmbito dos direitos e garantias fundamentais. São Paulo: Saraiva, 2008.

STEINMETZ, Wilson Antônio; AUGUSTIN, Sérgio (Org.). Direito constitucional do ambiente: teoria e aplicação. Caxias do Sul: EDUCS, 2011.

TOURAINE, Alain. O que é a democracia? 2. ed. Petrópolis: Vozes, 1996.

WESCHENFELDER, Paulo Natalicio. Do direito constitucional ao meio ambiente equilibrado: a construção de uma cultura. Caxias do Sul: EDUCS, 2012.

Como citar: MARIOTTI, Alexandre Abel; FERNANDES, Bruna Souza; LUNELLI, Carlos Alberto. Proteção ambiental, democracia representativa e acesso à justiça. Scientia Iuris, Londrina, v. 21, n. 3, p.9-42, nov. 2017. DOI: 10.5433/2178-8189.2017v21n3p9. ISSN: 2178-8189.

Recebido em 05/07/2016

Aprovado em 10/08/2017 